\title{
Host specificity of Spurgia esulae Gagné (Diptera: Cecidomyiidae), a gall midge introduced into the United States for control of leafy spurge (Euphorbia esula L. "complex")
}

\author{
P. PECORA, R. W. PEMBERTON, M. STAZI, and G. R. JOHNSON \\ Pecora and Stazi work at the Biological Control of Weeds Laboratory-Europe USDA-ARS, Rome, Italy. Mail address \\ American Embassy, Agric., APO New York 09794. Pemberton is with the Asian Parasite Laboratory, USDA-ARS, \\ Seoul, Korea. Mail address: American Embassy, APO San Francisco 96301. Johnson is with the Biological Control of \\ Weeds Laboratory, USDA, APHIS-PPQ,, 800 Buchanan Street, Albany, CA 94710.
}

\begin{abstract}
:
Spurgia esulae Gagné (=Bayeria capitigena Bremi of Solinas \& Pecora), a multivoltine gall midge recorded on Euphorbia esula in Italy, was selected as a candidate for the biological control of leafy spurge (Euphorbia esula L. "complex") in North America. Its potential host range was studied in 1982 at Rome, Italy, and in 1984 at Albany, Calif., using populations associated with Euphorbia esula from San Rossore near Pisa, Italy. Of 56 plant species or varieties in 22 families tested at the Rome laboratory, the midge oviposited and completed its life cycle only on plants in the genus Euphorbia (subgenus Esula). In the tests conducted in Rome, complete development occurred on five populations of North American leafy spurge (from Montana, Nebraska, North Dakota, Oregon, and Saskatchewan) and on European E. peplus L., E. cyparissas L., E. myrsinites L., E. characias L., E. serrulata Thuillier, and on E. lathyris L. from Chico and Castro Valley, Calif. Of 12 native North American Euphorbia species tested at Albany in 1984, four species in the subgenus Esula (E. incisa Engelmann, E. palmeri Engelmann, E. robusta (Engelmann) Small, and E. spathulata De Lamarck) supported the complete development of $S$. esulae. The restricted host range suggested use of this midge as a biological control agent against leafy spurge in North America. Releases of $S$. esulae were made in Montana in 1985 and in North Dakota in 1986; this species became established in both states.
\end{abstract}




\section{Keywords:}

Insecta, Spurgia esulae, Euphorbia spp., biological control.

Leafy spurge (Euphorbia esula L.), a weed of Eurasian origin, is probably an aggregate of closely related taxa (Radcliffe-Smith 1985). Its distribution in Eurasia extends across Europe from Norway, England, and Portugal in the west through Turkey, Iran, Afghanistan, and Pakistan (Croizat 1945). Pemberton (in press) also found leafy spurge in China, Japan, and Korea, and Bakke (1936) noted that North America and China represent the extremes of its distribution. This weed is an aggressive perennial, which spreads by seeds and by adventitious buds on its vigorous root system. According to Dunn (1985), it was introduced into North America during the last century on various occasions from different European sources. It has become a serious problem in pastures, ranges, and noncropland areas in the upper Great Plains of North America, infesting about 1 million ha (Noble et al. 1979).

One of the natural enemies of leafy spurge is a European gall midge, Spurgia esulae Gagné (=Bayeria capitigena Bremi of Solinas \& Pecora 1984 [Gagné 1990]). The larvae of this cecidomyiid cause meristematic tip galls, which prevent the flowering of the host plant and thus reduce seed production. A brief account of the biology of this species (as B. capitigena) was reported by Solinas \& Pecora (1984). Overwintering generations of $S$. esulae hibernate in the soil as mature larvae, which pupate during the spring. The mature larvae of the spring and summer generations pupate in the tip galls. At San Rossore near Pisa, Italy, the first galls produced by $S$. esulae larvae are usually found during the second half of April. New galls continue to appear on new plant growth until late October, indicating that this midge has four or five generations per year. Eggs are laid in groups on the leaves of the meristematic tip. Newly hatched larvae migrate to the meristematic tissue in the tips, where they feed and develop. The meristematic tissue of the infested apices is subjected to extensive hypertrophy, losing its meristematic character (Jauffret 1973). The mature larvae spin silken cocoons before pupating. Before emergence, the pupa ruptures the cocoon; then the pharate adult splits the pupal skin and emerges. When the tips of the host plant stems are killed by larvae feeding in the tip gall, the plant often produces secondary shoots below the dead tips. The tips of the secondary shoots are frequently attacked by subsequent generations of adults.

Buhr (1964), reporting the records of various authors, recorded "Bayeria capitigena" from Euphorbia esula, E. cyparissias L., E. dulcis L., E. verrucosa L., E. amygdaloides L., and E. virgata Waldstein and Kitaibel. Because this midge appeared to have the potential to reduce reproduction in Euphorbia spp., we selected it as a candidate for the biological control of leafy spurge. To determine its safety as a biological control agent, host specificity studies were conducted at the USDA-ARS laboratories at Rome, Italy, and Albany, Calif., from 1982 to 1984. The objective of the work at the Rome laboratory was to determine the host range of $S$. esulae at the plant genus level, whereas the objective of the Albany laboratory was to examine the potential host range on Euphorbia spp. that are native to North America. 


\section{Materials and methods}

\section{Rome testing 1982}

To test the range of plants that would support development of $S$. esulae, a list of 58 test plants in 22 families (Table 1) was compiled using Heywood (1978) as a guide. Plant species closely related to Euphorbia, and representative economic plants, were included among the test plants. The test plants were grown in baked clay pots $(20 \mathrm{~cm}$ diameter $)$ from seeds, cuttings, and root pieces.

Table 1. Plant species or varieties tested with $S$. esulae at the Rome Laboratory, 1982

\begin{tabular}{|c|c|}
\hline Plant and source & Type of test $\mathrm{a}^{\mathrm{a}}$ \\
\hline \multicolumn{2}{|l|}{ Euphorbiaceae } \\
\hline $\begin{array}{l}\text { Euphorbia esula L.* } \\
\text { Italy (control) }\end{array}$ & A, B \\
\hline $\begin{array}{l}\text { E. esula* } \\
\text { North Dakota }\end{array}$ & A \\
\hline $\begin{array}{l}\text { E. esula* } \\
\text { Nebraska }\end{array}$ & A, B \\
\hline $\begin{array}{l}\text { E. esula* } \\
\text { Oregon }\end{array}$ & A, B \\
\hline $\begin{array}{l}\text { E. esula* } \\
\text { Montana }\end{array}$ & $\mathrm{A}, \mathrm{B}$ \\
\hline $\begin{array}{l}\text { E. esula* } \\
\text { Saskatchewan }\end{array}$ & $\mathrm{A}, \mathrm{B}$ \\
\hline E. peplus L.* & $\mathrm{A}, \mathrm{B}$ \\
\hline E. characias L.* & A, B \\
\hline E. cyparissias $\mathrm{L} . *$ & $\mathrm{~A}, \mathrm{~B}$ \\
\hline E. myrsinites L.* & $\mathrm{A}, \mathrm{B}$ \\
\hline $\begin{array}{l}\text { E. lathyris L.* } \\
\text { Castro Valley, Calif. }\end{array}$ & A, B \\
\hline $\begin{array}{l}\text { E. lathyris L.* } \\
\text { Chico, Calif. }\end{array}$ & A, B \\
\hline E. serrulata Thuiller & $\mathrm{A}, \mathrm{B}$ \\
\hline E. marginata Pursh & A, B \\
\hline E. antisyphilitica Zuccarini & A \\
\hline E. pulcherrima Willdenow & A, B \\
\hline E. heterophylla L. & A, B \\
\hline E. milii Desmoulins & $\mathrm{A}, \mathrm{B}$ \\
\hline E. tirucalli $\mathrm{L}$. & $\mathrm{A}, \mathrm{B}$ \\
\hline Ricinus communis $\mathrm{L}$. & A, B \\
\hline Mercurialis anпиа $\mathrm{L}$. & A \\
\hline $\begin{array}{l}\text { Codiaeum variegatum (L.) Blume } \\
\text { var. picturn (Loddiges) Muller of Aargau }\end{array}$ & A, B \\
\hline Manihot palmata Muller of Aargau & A \\
\hline Pedilanthus tithymaloides (L.) Poiteau & A \\
\hline
\end{tabular}

Page 3 of 11 


\section{Rutaceae}

Ruta graveolens L.

A, B

Linaceae

Linum narbonense L.

A, B

Geraniaceae

Geranium rotundifolium L.

A, B

Erodium glutinosum L.

$\mathrm{A}$

Pelargonium zonale (L.) Aiton

A, B

Vitaceae

Vitis vinifera L.

A

Rosaceae

Rosa sp.

A, B

Umbelliferae

Daucus carota Hoffmann

A, B

Fabaceae

Phaseolus vulgaris L.

A, B

Medicago sativa L.

A, B

Onagraceae

Clarkia elegans Douglas

A, B

Apocynaceae

Nerium oleander L.

A, B

Vinca major L.

A, B

Asclepediaceae

Asclepias syriaca L.

A, B

A. curassavica L.

A, B

Solanaceae

Solanum tuberosum L.

A, B

Convolvulaceae

Ipomea batatas (L.) Lamark

A, B

Labiatae

Salvia splendens Sellow ex Roemer \& Shultes

A, B

Thymus serpyllum L.

A, B

Scrophulariaceae

Antirrhynum majus L.

A, B

Compositae

Lactuca sativa L. cv. Great Lakes

A, B

Cichorium antybus L.

A, B

Carthamus tinctorius L. cv. Dart

A, B

Page 4 of 11 


\begin{tabular}{|c|c|}
\hline Plant and source & Type of test $\mathrm{t}^{\mathrm{a}}$ \\
\hline Cynara scolymus L. & A \\
\hline Helianthus tuberosus L. & $\mathrm{A}, \mathrm{B}$ \\
\hline Sonchus arvensis L. & A \\
\hline \multicolumn{2}{|l|}{ Gramineae } \\
\hline Zea mays L., U.S. field corn variety $(\mathrm{B} 73 \times \mathrm{MO17})$ & A, B \\
\hline Z. mays, sweet corn, cv. Golden hybrid blend & A, B \\
\hline \multicolumn{2}{|l|}{ Liliaceae } \\
\hline Lilium sp. & A \\
\hline \multicolumn{2}{|l|}{ Brassicaceae } \\
\hline Brassica oleracea L. & A \\
\hline \multicolumn{2}{|l|}{ Moraceae } \\
\hline Ficus carica $\mathrm{L}$. & A \\
\hline F. elastica Roxburg & A, B \\
\hline \multicolumn{2}{|l|}{ Chenopodiaceae } \\
\hline Beta vulgaris L., cv. Early Wonder & A, B \\
\hline \multicolumn{2}{|l|}{ Ranunculaceae } \\
\hline Anemone sp. & $\mathrm{A}, \mathrm{B}$ \\
\hline
\end{tabular}

Larval survival test: Neonate larvae are easily injured, so mature eggs were transferred to the apical meristems of the various test plants with a moistened, fine brush. Eggs were obtained from caged adults that emerged from galls collected on E. esula at San Rossore during mid-May 1982. Each test plant, as well as each control plant, received 100 mature eggs distributed over five branch tips (20 eggs per tip), each tip serving as a replicate. To avoid any interference by feral adults of $S$. esulae, a transparent plastic cylinder (20 cm diameter, $60 \mathrm{~cm}$ high) with two screened air holes $(10 \mathrm{~cm}$ diameter) on each side and capped with nylon screen, was placed over each potted plant. As a check on percentage eclosion, 200 eggs from the same stock used in the trial were equally distributed between two 35-cc plastic cups and monitored daily for hatching. The experiment, conducted outdoors in a shaded area at $9-30^{\circ} \mathrm{C}$ and $30-80 \% \mathrm{RH}$, was started on 20 May and ended on 10 June 1982, when the meristematic tips were dissected and the numbers of larvae and pupae present were recorded.

Free-choice host suitability test: The objective of this experiment was to see if $S$. esulae would select nonhost plants for oviposition and larval development Test were obtained from 78 plants of E. esula, collected at San Rossore during late May 1982, each with 9-12 mature galls. A completely randomized plot ( 11.80 by $3.5 \mathrm{~m})$ was set up in the laboratory garden with 46 test plant species (treatments) plus the control, each replicated six times $(n=282$ pots). The 78 infested plants were randomly intermixed with the test plants so emerging flies would have equal access to all of the plants in the test. In all, there were 360 potted plants (test plants plus infested plants) distributed in 30 rows of 12 
potted plants per row. The pots were $10 \mathrm{~cm}$ apart, and there was a space of $20 \mathrm{~cm}$ between the rows.

The experiment was set up on 2 June 1982, and each test plant was checked for eggs daily for 10 days At the end of June, all tips showing signs of attack by the midge were dissected, and the numbers of living and dead larvae and pupae and exposed tips were counted.

Host specificity data were subjected to analysis of variance (ANOVA), and means were separated by a $t$ test (unplanned comparisons) (Sokal \& Rohlf 1981).

\section{Albany testing, 1984}

No-choice host suitability test: $S$. esulae was brought into quarantine at the Albany laboratory on the basis of host specificity testing done at the Rome laboratory, which showed the insect to be specific to the genus Euphorbia. To determine the potential host range within native American Euphorbia species, 12 plant species (including the plant control), representing the four subgenera (Agaloma, Chamaesyce, Esula, and Poinsettia) of the genus Euphorbia that occur in North America, were selected. Nine of the selected species are sympatric with leafy spurge, and eight may act as bridges to rare species (Pemberton 1985). Euphorbia purpurea (Rafinesque-Schmaltz) Fernald and E. telephiodes Chapman were test plants because they are under review as endangered species and are closely related to leafy spurge (subgenus Esula species). E. maculata L., E. supina Rafinesque-Schmaltz, and E. heterophylla L. were test plants because they are at times reported as weedy (Dunn 1979). E. marginata Pursh (snow on the mountain), E. corollata L. (flowering spurge), and E. heterophylla (fire plant) are cultivated as ornamentals. The test plants were grown in $15-\mathrm{cm}$ fiber pots from seeds, cuttings, and root pieces. The soil used was "UC mix," modified to match the edaphic conditions of the specific test species. The sex of freshly emerged adults of $S$. esulae was determined, and the specimens were placed in wooden screen sleeve cages ( 76 by 48 by $43 \mathrm{~cm}$ and 96 by 65 by $61 \mathrm{~cm}$ ) with plants of a single species. Because of varying availability and numbers of test plants and adults of $S$. esulae, the test was run in four series. In each series, 10 plants per native Euphorbia spp. and 5 control plants of E. esula were used, except for $E$. palmeri Engelmann and E. marginata, for which only five test plants were used. In the first three series, six adults (three females, three males) were used per individual potted plant. In the fourth series, three adults (two females, one male) were used per potted plant. The number of available tips that were galled, and the number of larvae and adults produced per plant species, were recorded. These studies were conducted from May to October 1984 at the Albany Laboratory. A $x^{2} 2 \times 2$ contingency test (Snedecor \& Cochran 1980) was used to compare the differences in the acceptability of the control of $E$. esula and the other Euphorbia species.

\section{Results}

\section{Rome testing, 1982}

Larval survival test: Of the 200 control eggs, 92\% hatched within 4 d.. S. esulae completed its development from egg to adult on 8 of 55 exposed test plants, all in the ge- 
nus Euphorbia (subgenus Esula), as well as on the control plant, E. esula. The formed galls were dissected $20 \mathrm{~d}$ after the beginning of the experiment. Compared with the control plant, the mean number of individuals (larvae and pupae) found per gall was significantly lower on E. characias L. and both populations of E. lathyris L. (from Chico and Castro Valley, Calif.). The percentage of larval and pupal mortality was significantly higher $(\mathrm{P}<0.05)$ on $E$. characias and E. lathyris (Castro Valley population).

Table 2. Results of $S$. esulae larval survival and free-choice host suitability tests, Rome Laboratory, 1982.

\begin{tabular}{|c|c|c|c|c|}
\hline \multirow[b]{2}{*}{ Test plants ${ }^{\mathrm{e}}$} & \multicolumn{2}{|c|}{$\begin{array}{l}\text { First-instar survival test, } \\
\quad \bar{x} \pm \mathrm{SD}(n=5)\end{array}$} & \multicolumn{2}{|c|}{$\begin{array}{l}\text { Free-choice host suitability test, } \\
\qquad \bar{x} \pm \mathrm{SD}(n=6)\end{array}$} \\
\hline & $\begin{array}{l}\text { No. larvae and } \\
\text { pupae per gall }^{\mathrm{a}}\end{array}$ & $\%$ Mortality $^{\mathrm{b}}$ & $\begin{array}{l}\text { No. exposed apical } \\
\text { tips per potted plant }\end{array}$ & $\%$ Galled tips ${ }^{\mathrm{d}}$ \\
\hline $\begin{array}{l}\text { Euphorbia esula } \\
\text { Italy (control) }\end{array}$ & $14.60 \pm 3.29 \mathrm{a}$ & $17.40 \pm 14.20 \mathrm{a}$ & $15.50 \pm 8.70 \mathrm{a}$ & $38.90 \pm 14.30 \mathrm{ab}$ \\
\hline $\begin{array}{l}\text { E. cyparissias } \\
\text { Italy }\end{array}$ & $14.50 \pm 3.32 \mathrm{a}$ & $31.90 \pm 14.30 \mathrm{ab}$ & $12.50 \pm 4.30 \mathrm{a}$ & $29.10 \pm 15.10 \mathrm{ab}$ \\
\hline $\begin{array}{l}\text { E. esula } \\
\text { Montana }\end{array}$ & $13.50 \pm 2.65 \mathrm{a}$ & $38.20 \pm 16.80 \mathrm{ab}$ & $5.50 \pm 2.50 b$ & $68.00 \pm 18.50 b$ \\
\hline $\begin{array}{l}\text { E. esula } \\
\text { Oregon }\end{array}$ & $12.75 \pm 3.59 \mathrm{a}$ & $31.60 \pm 12.20 \mathrm{ab}$ & $4.60 \pm 1.90 b$ & $47.90 \pm 27.40 \mathrm{ab}$ \\
\hline $\begin{array}{l}\text { E. esula } \\
\text { North Dakota }\end{array}$ & $11.75 \pm 4.11 \mathrm{a}$ & $8.70 \pm 11.00 \mathrm{ab}$ & \multicolumn{2}{|c|}{ Not tested } \\
\hline $\begin{array}{l}\text { E. esula } \\
\text { Nebraska }\end{array}$ & $11.00 \pm 2.74 \mathrm{a}$ & $17.00 \pm 12.70 \mathrm{ab}$ & $6.00 \pm 1.60 b$ & $46.10 \pm 32.20 \mathrm{ab}$ \\
\hline $\begin{array}{l}\text { E. esula } \\
\text { Saskatchewan }\end{array}$ & \multicolumn{2}{|c|}{ Apical tips completely destroyed } & $3.10 \pm 0.70 b$ & $20.50 \pm 23.10 \mathrm{ab}$ \\
\hline $\begin{array}{l}\text { E. peplus } \\
\text { Italy }\end{array}$ & $12.20 \pm 1.92 \mathrm{a}$ & $32.70 \pm 24.20 \mathrm{ab}$ & $18.30 \pm 6.50 \mathrm{a}$ & $26.80 \pm 6.70 \mathrm{ab}$ \\
\hline $\begin{array}{l}\text { E. lathyris }{ }^{f} \\
\text { Castro Valley, } \\
\text { Calif. }\end{array}$ & $7.75 \pm 0.96 b$ & $48.70 \pm 15.00 b$ & $1.00-$ & 100 \\
\hline $\begin{array}{l}\text { E. lathyris } \\
\text { Chico, Calif. }\end{array}$ & $4.20 \pm 2.20 \mathrm{~b}$ & $21.00 \pm 21.33 \mathrm{a}$ & $1.00-$ & 100 \\
\hline $\begin{array}{l}\text { E. characias } \\
\text { Italy }\end{array}$ & $7.40 \pm 4.16 b$ & $83.60 \pm 22.30 c$ & $5.80 \pm 1.90 b$ & No galls \\
\hline $\begin{array}{l}\text { E. serrulata } \\
\text { France }\end{array}$ & \multicolumn{2}{|c|}{ No development of larvae } & $11.30 \pm 2.60 \mathrm{a}$ & $11.40 \pm 18.00 \mathrm{ab}$ \\
\hline E. myrsinites & \multicolumn{2}{|c|}{ No development of larvae } & $4.30 \pm 1.80 \mathrm{~b}$ & $16.60 \pm 21.00 \mathrm{ab}$ \\
\hline $\begin{array}{l}\text { Means in columns f } \\
\text { a Number of larvae } \\
{ }^{b} \text { Percentage mortali } \\
{ }^{\mathrm{c}} \text { Number of expose } \\
{ }^{\mathrm{d}} \text { Percentage galled } \\
{ }^{\mathrm{e}} \text { The other test plan } \\
{ }^{\mathrm{f}} \text { Each plant had onl }\end{array}$ & $\begin{array}{l}\text { by the same letter } \\
\text { ae per gall (F } 18.35 \\
5.77 ; \mathrm{df}=9,35 ; \mathrm{P} \\
\text { tips per plotted pla } \\
=3.70 ; \mathrm{df}=7,40 ; \mathrm{P} \\
\text { sted in Table } 1 .\end{array}$ & $\begin{array}{l}\text { not significantly diffe } \\
=10,147 ; \mathrm{P}<0.05) \\
5) \\
\mathrm{F}=10.02 ; \mathrm{df}=9,50 \\
.05)\end{array}$ & $\begin{array}{l}\mathrm{P}<0.05) \\
(\mathrm{P}=0.05 ; t \text { test })\end{array}$ & \\
\hline
\end{tabular}


Free-choice host suitability test: From 20 galls set aside to quantify adult emergence, 30 females and 42 males of $S$. esulae ( $\bar{x}, 3.60$ adults per gall) emerged. Assuming that the 780 galls used in the trial had the same level of infestation, about 2,800 adults of $S$. esulae were present in the experimental plot. The midge selected only plants in the genus Euphorbia (subgenus Esula) for oviposition and larval development. Larvae of S. esulae developed on all test plants on which oviposition occurred, except on E. characias. Furthermore, gall formation occurred on E. serrulata Thuiller and E. myrsinites L., whereas no gall development was observed on these plant species in the previous larval survival trial. Compared with the ltalian plant control, the percentage of galled tips was significantly greater on E. esula from Montana, whereas no significant differences were found on the other test plants. All exposed apical tips of E. lathyris, from Chico and Castro Valley, were attacked by the midge.

\section{Albany Testing, 1984}

No-Choice Host Suitability Test. S. esulae oviposited on 7 of the 11 North American Euphorbia species tested (five species in the subgenus Esula and one species in the subgenera Agalorma and Chamaesyce, respectively), as well as on the plant control. E. incisa Engelmann, E. palmeri Engelmann, E. robusta (Engelmann) Small, and E. spathulata De Lamarck (all in the subgenus Esula) supported the full development of $S$. esulae. Incompletely developed galls containing a few dead larvae occurred on E. telephiodes Chapman (a rare species of the subgenus Esula), E. maculata L. (subgenus Chamaesyce), and E. corollata L. (subgenus Agaloma) (Series II, III, and IV). Because of the oviposition and gall initiation on E. telephiodes, E. maculata, and E. corollata, these species were retested (Series IV). The results were similar to those of the former series where oviposition and some gall initiation occurred but where there was not full gall formation or development to the adult stage. Among those plant species that supported full development of $S$. esulae, the percentage of plant acceptability, with the $x^{2} 2 \times 2$ contingency test $(\mathrm{P}=0.0032)$, was significantly different on E. palmeri $(60 \%)$, E. spathulata $(40 \%)$, E. corollata $(40 \%)$, E. robusta $(10 \%)$, and E. telephiodes $(10 \%)$ compared with the plant control (E. esula; $100 \%$ galled) (Series III), whereas in Series IV, there was no significant difference comparing E. esula (100\% galled) and E. robusta ( $80 \%$ galled). 
Table 3. S. esulae no-choice suitability test on native North American Euphorbia species, Albany, 1984.

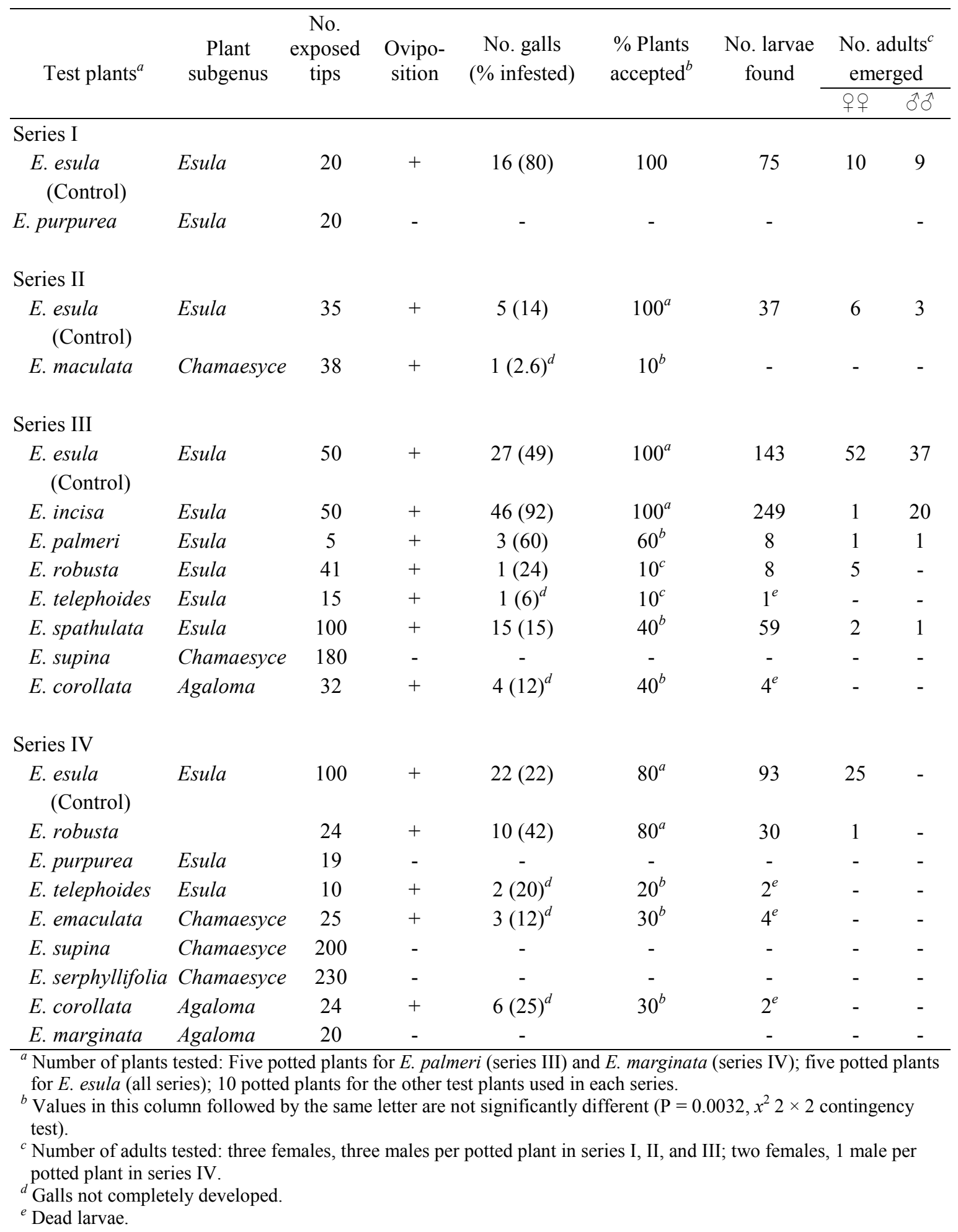




\section{Discussion}

Although some gall midges are oligophagous, others are restricted to one host (Nijveldt 1969, Gagné 1989). Species of the genus Spurgia are apparently monophagous. $S$. esulae has been recorded in nature only on E. esulae (Gagné 1990). Our host specificity testing indicated that this midge is able to oviposit and complete its development in the laboratory on a restricted number of species in the subgenus Esula of the genus Euphorbia. In the Rome larval survival test, this midge did not develop on E. serrulata or $E$. myrsinites, but in the Rome host suitability test some larvae completed development on these species. We are not sure why larvae failed to develop in the first test; possibly the plants on which the eggs were placed were in the wrong phenophase for development of the larvae. E. characias had the highest percentage of larval mortality (83.6\%), with only a few larvae maturing. In the host suitability test, the females oviposited in E. characias but no galls developed. E. characias is probably a marginal host, having the proper attractants for oviposition but lacking the proper morphology, nutrient content, or gallforming mechanism for the satisfactory development of $S$. esulae larvae.

Spurgia esulae appears, from no-choice host suitability tests made at the Albany laboratory, to be restricted to at least the subgenus Esula level. E. incisa appears to be as acceptable as a host as E. esula, but it is a southwestern desert species that is distributionally separate from the immigrant E. esula except possibly in Nevada. There are 21 species of the subgenus Esula in America north of Mexico (Pemberton 1985). $S$. esulae did not develop on either of the rare subgenus Esula species (E. purpurea, E. telephiodes), thus reducing the potential number of potential host plants from 21 to 19 . Because these two species were not accepted as host plants, probably other species in the subgenus (which were not tested) would also prove to be unacceptable.

The host specificity testing indicated that the host range of $S$. esulae is broad enough to accept the diverse hybrids and forms of leafy spurge and yet narrow enough to exclude most native North American Euphorbia species. Field releases of S. esulae against leafy spurge were first made in Montana in 1985 and in North Dakota in 1986; this species became established in both states (R.W.P. \& N. E. Rees, USDA-ARS, Rangeland Weeds Laboratory, unpublished data).

\section{Acknowledgment}

We thank the Italian Ministry of Agriculture for giving permission to conduct our studies in the hunting preserve at San Rossore. We also thank G. B. Buckingham (Plant Stress and Protection Research, USDA-ARS, Gainesville. Fla.); R. J. Gagné (Systematic Entomology Laboratory, USDA-ARS, Washington, D.C.); and P. H. Dunn, L. Knutson, and R. Sobhian (Biological Control of Weeds Laboratory, USDA-ARS, Rome) for reviewing the manuscript.

Page 10 of 11 


\section{References cited}

Bakke, A. L. 1936. Leafy spurge, Euphorbia esula L., pp. 209-245. In Iowa Research Station Bulletin 189.

Buhr, H. 1964. Bestimmungstbellen der Gallen (Zoound Phytocecidien) an Pflanzen Mittel-und-Nordeuropas (2 vols.). Gustav Fisher, Jena.

Croizat, L. 1945. "Euphorbia esula" in North America. Am. Midl. Nat. 33:231-243.

Dunn, P. H. 1979. The distribution of leafy spurge (Euphorbia esula) and other weedy Euphorbia spp. in the United States. Weed Sci. 27: 509-516.

Dunn, P. H. 1985. Origin of leafy spurge in North America, pp. 7-13. In A. K. Watson [ed.] Monograph Series No. 3, Weed Science Society of America, Champaign, Ill.

Gagné, R. J. 1989. The plant-feeding gall midges of North America. Cornell University Press, Ithaca NY.

Gagné, R. J. 1990. The gall midge complex (Diptera: Cecidomyidae) in bud galls of Palearctic Euphorbia (Euphorbiaceae). Ann. Entomol. Soc. Am. 83:335-345.

Heywood, V. H. 1978. Flowering plants of the world. Mayflower, N.Y.

Jauffret, F. 1973. Etude ultrastructurale de la formation du meristeme apical de l'Euphorbia cuparissias L. en tissu nouricier sous l'action du Bayeria capitigena (Brec.). C. R. Acad. Sci. Paris Ser. D 276(7):1177-1180.

Nijveldt, W. 1969. Gall midges of economic importance VII. Miscellaneous. Crosby Lockwood, London.

Noble, D., P. Dunn \& L. Andres. 1979. The leafy spurge problem, pp. 8-15. In Proceedings of the leafy spurge symposium. North Dakota State University, Cooperative Extension Service, Bismarck.

Pemberton, R. W. 1985. Native plant consideration in the biological control of leafy spurge, pp. 365-390. In E. S. Delfosse [ed.] Proceedings of the VI International Symposium on the Biological Control of Weeds, Vancouver, Canada.

Pemberton, R. W. 1990. Northeast Asia as a source of biological control agents for North American weeds, pp. 651-657. In E. S. Delfosse [ed.] Proceedings of the VII International Symposium on the Biological Control of Weeds, Rome, Italy.

Radcliffe-Smith, A. 1985. Taxonomy of North American leafy spurge, pp. 14-25. In A. K. Watson [ed.] Monograph Series, No. 3, Weed Science Society of America, Champaign, Ill.

Snedecor, G. W. \& W. C. Cochran. 1980. Statistical methods. Iowa State University Press, Ames.

Sokal, R. R. \& F. J. Rohlf. 1981. Biometry, 2nd ed. Freeman, San Francisco.

Solinas, M. \& P. Pecora. 1984. The midge complex (Diptera: Cecidomyidae) on Euphorbia spp. I. Entomologica 19:167-213. 